\title{
The Rise of Bioethics: A Historical Overview
}

\begin{abstract}
The bioethics movement did not arise and expand in a vacuum. As discussed in this chapter, advances within medicine were creating a need for ethical issues to be identified and addressed. Major new work in philosophy suggested that philosophically trained "bioethicists" could uniquely contribute to ethics in medicine. The growing momentum of the consumer rights movement lent its particular, rights-oriented contours to bioethics and the demands it placed on physicians. Likewise, courts were giving legal force to the rights of patients against doctors. These diverse forces coalesced into a worldwide movement-despite the mixed response in Europe and elsewhere-that came to dominate the scholarly literature in health care ethics (not just in medicine) and that set itself as a model for how health professionals were supposed to think about clinical ethics.
\end{abstract}

Keywords Health care - Clinical ethics - Hastings Center - Kennedy Institute of Ethics - Consumer rights - Patient rights - American bioethics - European bioethics - Fritz Jahr - Universal Declaration on Bioethics and Human Rights

\section{Modest Beginnings}

The modern era of health care ethics is often traced to Henry Beecher's influential, 1966 article on ethical problems in clinical research, with particular attention (through a series of actual examples) to the

(C) The Author(s) 2018

S. Scher and K. Kozlowska, Rethinking Health Care Ethics, https://doi.org/10.1007/978-981-13-0830-7_3 
failure to inform patients of the risks involved in experimental treatments (Beecher 1966). Beecher, a professor of anesthesiology at Harvard Medical School, soon followed that article with another, also published in the New England Journal of Medicine, on the ethical problems in caring for "hopelessly unconscious patients" (Beecher 1968). In this second article Beecher gave particular attention to the problem of determining when medical treatment could be discontinued. He well recognized that the issues addressed in both of these articles were the product of the explosive, postwar growth of medical research and the resulting, unprecedented advances in understanding and treating disease. That is, these unprecedented advances carried with them equally unprecedented ethical problems in the care of patients.

Beecher's approach to addressing these ethical problems was simple. He had published these articles in the United States' leading medical journal, whose primary audience was his fellow physicians and clinical researchers; he had identified the problems concretely and with precision; and he expected the medical profession-and even individual researchers and health care providers - to take appropriate action. For example, in the case of the problems that he had identified in clinical research, he reasoned that the most "reliable safeguard" of the patient's interests - and against unethical behavior - was "the presence of an intelligent, informed, conscientious, compassionate, responsible investigator" (Beecher 1966, p. 1360). ${ }^{1}$

\section{The Hastings Center and Kennedy Institute of Ethics}

The world of health care ethics did not remain that simple for long. New problems were emerging faster than the medical profession, without an immediate, large-scale, and immediate effort, could itself address. The result was a developing, and growing, gap between the profession's established practices, ethical and otherwise, and the public's need to address the problems that emerged as modern medicine extended its scientific and clinical powers. The gap was soon filled by the founding in 1969 of the Hastings Center/Institute of Society, Ethics and the Life Sciences, a signal event in the development of modern health care ethics. The new field that took shape was called bioethics-a term explicitly chosen to encompass not only medicine and the rest of health care, but the entire field of the (human) life sciences (Callahan 1971, 1973). The Hastings Center-located in the village of Hastings-on-Hudson, 
just north of New York City-took the lead in setting the direction, methods, and intellectual standards of bioethics through its own journal, the Hastings Center Report (Callahan 1971, 1973). The Kennedy Institute of Ethics at Georgetown University, another bastion of bioethics, was founded two years later, in $1971 .^{2}$

In order to understand the direction, both short and long term, taken by the Hastings Center and Kennedy Institute of Ethics, by their growing number of advocates (especially from outside the medical profession), and by the bioethics literature itself, it is helpful to understand the social, legal, political, and intellectual environment in which the Center and Institute developed.

\section{The Rise of Scientific Medicine}

Until penicillin and sulfa drugs were developed and introduced in the late 1930s, the scientific revolution of the late nineteenth and early twentieth centuries had yet to generate major advances in the treatment of disease. $^{3}$ The practice of medicine remained largely "empiric" - that is, based directly on physicians' collective, historical observations of what helped patients, rather than on the scientific understanding of disease processes and how to affect them. Much of the physician's work remained, by default, supportive and palliative. In comparison to our present health care system, public expenditures for medical care were minimal. Almost all physicians were private practitioners paid directly by their patients. The medical profession was essentially self-regulating, with legal regulation of medicine verging on the nonexistent. Hospitals were simple institutions compared to the complex behemoths we are all too familiar with today. And the traditional medical ethic, centered on the Hippocratic Oath and basically unchanged for twenty-five hundred years, continued to serve patients and physicians well.

Following World War II, the rate of scientific and therapeutic progress rapidly accelerated. Sulfa drugs and penicillin had saved countless lives during the war, which had also seen impressive advances in surgery and in the treatment of traumatic injuries. In the United States (and also in Europe), public and private funding of scientific research increased dramatically, fueled by expectations that further advances were just over the horizon. The highly visible and successful introduction of the polio vaccine in the early 1950s served to legitimize these expectations, which soared yet again. The era of modern medicine had begun in earnest. 
Over the next two decades, unprecedented advances in the understanding and treatment of disease created an environment of almost unqualified optimism within the medical profession. Radiation therapy, chemotherapy, treatments for advanced heart disease, and hundreds of new and powerful drugs came into common use. With access to the diagnostic tools, medical treatments, surgical procedures, and technology of modern medicine, physicians considered themselves to be worthy opponents of the most devastating illnesses: pneumonia, heart disease, even cancer. Military metaphors came to pervade the language of medicine. Physicians "fight" or "combat" disease, which is the "enemy." Bacteria "invade" the body, which has its own "defenses." Radiation therapy "destroys" or "kills" tissues. The drugs available for use against cancer are referred to individually as "weapons," collectively as an "armamentarium." The research effort to discover cures for cancer came to be known as the "war on cancer." 4 The battle against disease was being waged and-so it seemed-won.

In the exhilarating days of mid-twentieth-century medicine, physicians saw themselves as applied scientists who marshalled the diverse technical resources of modern medicine against the onslaught of disease. The physician's exclusive tasks were to identify pathological processes and to determine which surgical and pharmacological interventions were necessary to eradicate disease and its symptoms. Physicians were trained to provide aggressive, unrelenting treatment for all diseases; only a patient's death would signal defeat. ${ }^{5}$

Within this framework, physicians perceived the patient as little more than the locus of disease:

The human body belongs to the animal world. It is put together of tissues and organs, in their structure, origin, and development not essentially unlike what the biologist is otherwise familiar with; it grows, reproduces itself, decays, according to general laws. It is liable to attack by hostile physical and biological agencies; now struck with a weapon, again ravaged by parasites. (Flexner 1910 , p. 53$)^{6}$

Patients' needs were thus defined medically, exclusively in terms of their diseases. The role of patients remained the same as it had been throughout the history of medicine: to trust their physicians and to submit passively to whatever treatments their physicians deemed appropriate. Except for the need to administer pain medications, physicians 
dismissed pain and suffering as merely subjective phenomena that were no more than the unfortunate and unavoidable consequences of disease. And since physicians' overriding obligations remained-as they always had been-to diagnose and treat disease, the personal preferences of patients had no impact on, or relevance to, physicians' medical decisions. Physicians' authority over their patients was complete and absolute.

\section{Patient Rights and Consumer Rights}

Physicians' inattention to patients' subjective experiences and preferences proved to be one of the central shortcomings of scientific medicine. As early as the 1957 Salgo case, courts recognized that physicians' unilateral decisions could lead to results at variance with patients' own interests and goals. The plaintiff in Salgo had sued to recover damages for what he claimed was the negligent performance of a diagnostic procedure, an aortography, in which dye was injected into the aorta to determine whether it was blocked. On awakening the day after the procedure, his legs were paralyzed. In addition to the original complaint for negligence, the plaintiff later appended a further claim that his physicians had been negligent in failing to warn him of the risks associated with the procedure. In a decision that awarded damages to the plaintiff, the court announced a new legal doctrine-informed consent-that required physicians to provide patients with all relevant information about available treatment alternatives. It was the patient, not the physician, who should decide how to balance the risks and benefits associated with any particular procedure or treatment. In so restricting physicians' traditional authority to control the course of medical treatment, the doctrine was specifically designed to ensure that patients' preferences were incorporated into the process of making medical decisions.

Notwithstanding the Salgo case, events within the broader American society would prove to be the driving force behind, give a sense of mission to, and even substantially shape the bioethics movement. These developments would soon outpace Beecher and his efforts to mobilize the medical profession as the vanguard of a new medical ethic.

In 1962, President John F. Kennedy presented a landmark address to the U.S. Congress about the rights of consumers (Kennedy 1962), which he described as follows: 
1. The right to safety-to be protected against the marketing of goods which are hazardous to health or life.

2. The right to be informed-to be protected against fraudulent, deceitful, or grossly misleading information, advertising, labeling, or other practices, and to be given the facts he needs to make an informed choice.

3. The right to choose-to be assured, wherever possible, access to a variety of products and services at competitive prices; and in those industries in which competition is not workable and Government regulation is substituted, an assurance of satisfactory quality and service at fair prices.

4. The right to be heard-to be assured that consumer interests will receive full and sympathetic consideration in the formulation of Government policy, and fair and expeditious treatment in its administrative tribunals.

In addition to defining the above rights, Kennedy (1962) also noted the following:

Consumers, by definition, include us all. They are the largest economic group in the economy, affecting and affected by almost every public and private economic decision. Two-thirds of all spending in the economy is by consumers. But they are the only important group in the economy who are not effectively organized, whose views are often not heard.

Kennedy's solution to consumers' lack of organization and lack of voice was to define a new role for the federal government:

Additional legislative and administrative action is required . . . if the federal Government is to meet its responsibility to consumers in the exercise of their rights. ... To promote the fuller realization of these consumer rights, it is necessary that existing Government programs be strengthened, that Government organization be improved, and, in certain areas, that new legislation be enacted.

But asserting a new role for the federal government was not the same thing as organizing consumers or giving them the voice that they lacked. That process was set in motion, however, by the 1965 publication of Ralph Nader's Unsafe at Any Speed - the seminal event in the emergence 
of the consumer rights movement in the United States. Of special note was the ideology that the book brought to the marketplace of ideasnamely, that consumers should assert their ethical and legal rights against large and powerful corporations as a means of controlling them and protecting consumers from outright corporate misconduct and from poorly designed or unsafe products; such powerful organizations had shown themselves unworthy of the public's trust. Suddenly, the skeletal framework of consumer rights described by President Kennedy took form in a movement that would change the power relationships between consumers and corporations - and, in time, between consumers and anyone providing them with goods or services, including professional services of any kind.

\section{Applied Ethics and the Consolidation of Bioethics}

During this same time period, American academics were becoming actively involved in issues of ethics and public policy, primarily but not exclusively as a result of widespread opposition within the academic community to the war in Vietnam. And the publication in 1971 of John Rawls's A Theory of Justice - considered by many philosophers the most important book of moral and political philosophy of the twentieth century-instilled in the philosophical community a sense of confidence that genuine progress was being made, and that more was to come. Rawls's book was important in two ways, both of which fed this new sense of confidence. First, the book integrated a vast range of problems within the history of Western moral and political philosophy-problems that had often been discussed separately, without a broader sense of how they were related to other problems. Suddenly, as it were, the history of ethics and political philosophy could be understood as an integrated whole. Second, the book set forth a new way of thinking about ethical reasoning and of how to move from theoretical assumptions to actual ethical conclusions. That is, the book bridged ethical theory and normative ethicstheory and practice-in a way that brought dynamic new life to this area of philosophy.

But this philosophical honeymoon did not last long. A Theory of Justice generated a spectacular burst of philosophical activity, much supportive of Rawls's theory and his arguments, but also much that was critical. More broadly, and despite its initial optimism, the philosophical community came to appreciate how difficult it was to make progress either in ethical theory or in normative ethics - that is, in using the tools 
of moral philosophy to analyze, solve, and reach consensus on problems encountered in the real world. The challenge of applying philosophical theory to normative problems was far more difficult than they had hoped.

It was during this same period of the 1970s, however, that the small but rapidly growing group of bioethicists-many of whom were associated, in one way or another, with the Hastings Center or Kennedy Institute-effectively separated themselves from the mainstream of moral philosophy and established what was to become the new discipline of bioethics. And, whereas academic moral philosophy had taken on a new modesty concerning what was coming to be called applied ethics, the new field of bioethics witnessed a burst of theory construction, concept formation, problem identification, and conceptual clarification of the kind associated with the formative period of any new field of study (Callahan 1973).

With surprising rapidity, this new academic discipline came to have its own training programs, research centers, journals, tenure-track positions, funding sources, professional organizations, and national and international conferences. Philosophers, sociologists, theologians, lawyers, commissions, courts, and legislatures were the new, and authoritative, voice for ethics in medicine. By the early 1980s, little over a decade after the founding of this new field, bioethics and bioethicists had come to dominate not only public discussions of health care ethics in the United States but also, increasingly, the teaching of ethics in medicine, public health, nursing, and all of the allied health professions. A decade later, in 1991, the International Association of Bioethics was founded. Signaling the worldwide reach of the bioethics movement, the inaugural World Congress of Bioethics took place the following year in the Netherlands. The thirteenth such conference, with 700 delegates from 44 countries, was held in Edinburgh in 2016.

As might be expected, given the society-wide ferment associated with the American consumer rights movement beginning in the late 1960s, the emerging bioethical paradigm placed the rights of patients - the consumers in medicine - at the center of its theorizing. In Unsafe at Any Speed, Nader had drawn attention to the challenge of "defining values relevant to ... new technolog[ies] laden with risks," and he noted that a "great problem of contemporary life is how to control the power of economic interests which ignore the harmful effects of their applied science and technology" (Nader 1965, p. vii). 
The public, moreover, did not have the expertise and information required to identify those harmful effects or the attendant risks. The question was whether the relevant actors-corporations in the case of the automobile, and doctors and the organized medical profession in the case of medicine-could or would identify and in some way address the "inherent but latent dangers" (p. vii). And just as Nader had identified the lack of public trust in automobile manufacturers and in their capacity to address safety issues on their own (pp. 248-249), so would the public perceive the entrenched interests of doctors, individually and also collectively as an organized profession, as a pervasive obstacle to be overcome in protecting the rights and interests of patients (Starr 1982).

In this context, Beecher's two articles in the New England Journal of Medicine (Beecher 1966, 1968) represented a fleeting instant in which the medical profession recognized, and came close to seizing, what might be called the ethical moment. Instead, the bioethics movement seized that moment for itself, and the medical profession and subsequently the other health care professions-ranging from nursing to social work to clinical psychology to public health-found that bioethicists had staked their own claim to knowing the path forward.

\section{American Bioethics and Its (European) Discontents}

It is perhaps not surprising that a movement with such distinctive American social and intellectual roots might run into some sort of resistance elsewhere. ${ }^{7}$ As Amir Muzur notes in "European Bioethics: A New History Guaranteeing a New Future" (2017), through nearly the end of the twentieth century, the principlism at the core of American bioethics-the "Georgetown mantra" (p. 63) of autonomy, beneficence, nonmaleficence, and justice-was a "globally predominant doctrine" (p. 61) that, even so, had been adopted only slowly and with ambivalence in Europe. There, as in America, ongoing advances in medicine presented a pressing need for substantive ethical discussion and for decisions on matters of public policy, but efforts to "Europeanise" bioethics by "revising the set of [four] principles" (p. 61) had yet to generate a new model to replace it. ${ }^{8}$

Rolf Löther's 1998 rediscovery of the work of Fritz Jahr, ${ }^{9}$ a German theologian whose writings span the full second quarter of the twentieth century, set things on a new course (Jahr 1927). Jahr had used the 
term Bio-Ethik in establishing a bioethical imperative that was parallel to Kant's categorical imperative; it was a moral principle defining an ethical stance to the whole of nature, not just to one's fellow humans. And Jahr himself saw this principle as the product of a long, ongoing European intellectual tradition. For the Europeans looking to find a new way forward, Jahr's work was foundational, preceded the emergence of American bioethics, and set the stage for a distinctively European approach to the field. As Muzur notes (2017), Jahr's work has generated a whole series of distinctive and separate national approaches-in Europe and beyond - that leave open whether some future consolidation, toward some shared or universal set of principles, will prove possible.

As a footnote to these ongoing developments (with uncertain outcome) in Europe, we think it worth noting that the discontinuity between Jahr's work and American bioethics is deeper and more long-standing than the above summary suggests. Continental and Anglo-American philosophy broke off in separate directions after Kant (1724-1804). Fichte, Hegel, Schleiermacher, Husserl, and Heidegger are some of the leading figures on the Continental side, whereas Bentham, Mill, Russell, Ayer, and Wittgenstein are some on the AngloAmerican side. The most tangible difference between these two lines of philosophy is that the latter is oriented toward language, science, and intellectual precision, whereas the former sees knowledge more broadly and would generally consider the ways of science as only one wayand at that, a very constrained or limited way-of understanding ourselves and the world. In that context, Jahr's work has been, at least for Europeans, truly liberating, for it points to foundations in their own intellectual history that are unconnected with the Anglo-American roots of American bioethics.

\section{The Universal Declaration on Bioethics AND Human Rights}

For all the above activity in Europe-which is, to be sure, still playing itself out - the globally dominant conception of bioethics remains closely connected with principlism, the "Georgetown mantra." The first nine of the fifteen articles of the Universal Declaration on Bioethics and Human Rights, adopted by the United Nations Educational, Scientific and Cultural Organization in 2005, include all of the original four principles from that principlist framework and draw out their consequences. 
The remaining six articles address broader social dimensions of bioethics not covered by the original four principles: respect for cultural diversity and pluralism (Article 12), solidarity and cooperation (Article 13), social responsibility and health (Article 14), sharing of benefits (Article 15), protecting future generations (Article 16), and protection of the environment, the biosphere, and biodiversity (Article 17). Few bioethicists would find reason to dispute any of these additions, and any bioethicist committed to the four principles would likely see these additional principles (except, perhaps, for the not-so-Anglo-American Article 13 on solidarity, which comes directly out of the French, not American, Revolution) as simple extensions or even consequences of the original four.

Ten years after the adoption of the Universal Declaration, UNESCO published Global Bioethics: What For? (2015), a publication marking the twentieth anniversary of the organization's Bioethics Programme. Although one does see in the essays some effort to move beyond principlism, its presence remains strong and confining. As noted in the volume's introduction, the ongoing challenge for UNESCO's Bioethics Programme is to implement the principles of the Universal Declaration and "to make the ethical principles a reality" (p. 8). In this context, one contributor-Jean Martin, a general-practice physician/clinician, not a bioethicist - notes that the principles of the Universal Declaration remain the "fundamental points of reference" for bioethical teaching and discussion; bioethics itself, so conceived, with principles as the core, "must be a strong component in syllabuses-at schools, universities and professional or general training courses" (Martin 2015, p. 30).

Whether one thinks in terms of the original four principles or the expanded set of principles in the Universal Declaration on Bioethics and Human Rights, our concern remains the same. What happens when these sorts of ethical principles meet the very concrete world of clinical practice and the day-to-day clinical challenges of health professionals? That is the question we explore in the next two chapters.

\section{Notes}

1. This same sentiment is reflected, a decade later, in the following remark by a surgeon commenting on the potential use of review boards to determine suitable candidates for psychosurgery: 
"What I resent, and resent very deeply, is the idea that has been prevalent for the past seven years that patients have to be protected from physicians. This is a terrible, terrible thought to me. The best guardian that you can have of your welfare when you are ill with anything is your physicians." From Sue Sprecher, "Psychosurgery Policy Soon to Be Set," Real Paper, January 21, 1978. (as quoted in Paul Starr, The Social Transformation of American Medicine, p. 390)

2. See David J. Rothman's Strangers at the Bedside (1991) for a full history of the bioethics movement's first two decades.

3. One noteworthy exception concerned surgical interventions for the treatment of acute disease, an advance made possible by Lister's work on antisepsis and the subsequent development of sterile surgical technique. Another was the development of a vaccine for smallpox.

4. There may be something of the American character in this. The United States also had a war on poverty and a war on drugs.

5. The medical profession's difficulty in accepting that a patient is dying continues into the present day (Ivory 2016).

6. This quotation is taken from Abraham Flexner's visionary, early-twentieth-century study of medical education, Medical Education in the United States and Canada: A Report to the Carnegie Foundation for the Advancement of Teaching.

7. Here we have intentionally played on the title of Freud's Civilization and Its Discontents.

8. As Muzur notes $(2017$, p. 64 ), efforts to export the four principles revealed discontinuities between those principles and the values of the rest of the world.

For instance, while autonomy has been crucial for the AngloAmerican culture ever since Independence, in Europe the principle of solidarity is more important. In Eastern-Asian bioethics, autonomy again happens to be interpreted in the Confucian sense, i.e. stressing the sovereignty of family instead of the individual which is similar to what we can observe in some African cultures as well.

9. Jahr's most widely read essay is "Bio-Ethik. Eine Umschau überdie ethischen Beziehungen des Menschen zu Tier und Pflanze" (1927), translated under the title "Bio-Ethics. Reviewing the Ethical Relations of Humans Towards Animals and Plants" by Hans-Martin Sass in the Croatian journal JAHR (2010). The journal changed its subtitle from Annual of the Department of Social Sciences and Medical Humanities to European Journal of Bioethics in 2014 (volume 5), and may be, in library catalogs (including Harvard University's Harvard Online Library Information System [HOLLIS]), located only under that title (not $J A H R$ ). Jahr's essays are available in English transition in Essays in Bioethics, 1924-1948. 


\section{REFERENCES}

Beecher, H. K. (1966). Ethics and clinical research. New England Journal of Medicine, 274(24), 1354-1360. https://doi.org/10.1056/NEJM196606162742405.

Beecher, H. K. (1968). Ethical problems created by the hopelessly unconscious patient. New England Journal of Medicine, 278(26), 1425-1430. https://doi. org/10.1056/NEJM196806272782605.

Callahan, D. (1971). Values, facts, and decision-making. Hastings Center Report, $1(1), 1$.

Callahan, D. (1973). Bioethics as a discipline. Hastings Center Studies, 1(1), 66-73.

Flexner, A. (1910). Medical education in the United States and Canada: $A$ report to the Carnegie foundation for the advancement of teaching. New York: Carnegie Foundation for the Advancement of Teaching.

Ivory, K. D. (2016). The acute care conveyor belt: A personal experience. Medical Journal of Australia, 204(4), 162-163.

Jahr, F. (1924-1948). Essays in bioethics, Berlin: Lit, [2013] English language edition (I. M. Miller \& H.-M. Sass, Trans. and Eds., Ethik in der Praxis. Materialien; Bd. 15).

Jahr, F. (1927). Bio-Ethik: Eine Umschau über die ethischen Beziehungen des Menschen zu Tier und Pflanze [Bioethics: A review of man's ethical relationship with animals and plants]. Kosmos, 24(1), 2-4.

Jahr, F., \& Sass, H.-M. (Trans.). (2010). Bio-ethics: Reviewing the ethical relations of humans towards animals and plants. JAHR European Journal of Bioethics, 1(2), 227-231.

Kennedy, J. F. (1962). Special message to the Congress on protecting the consumer interest. http://www.jfklink.com/speeches/jfk/publicpapers/1962/ jfk93_62.html; http://www.presidency.ucsb.edu/ws/?pid=9108.

Löther, R. (1998). Evolution der Biosphare und Ethik. In E. M. Engels, T. Junker, \& M. Weingarten (Eds.), Ethik der Biowissenschaften: Geschichte und Theorie-Beiträge zur 6. Jahrestagung der Deutschen Gesellschaft für Geschichte und Theorie der Biologie (DGGTB) in Tübingen 1997 (pp. 61-68). Berlin: Verlag für Wissenschaft und Bildung.

Martin, J. (2015). Bioethics at UNESCO: Challenges and needs. In G. Solinís (Ed.), Global bioethics: What for? 20th anniversary of UNESCO's Bioethics Programme (pp. 27-30). Paris: UNESCO. http://unesdoc.unesco.org/images $/ 0023 / 002311 / 231159$ e.pdf.

Muzur, A. (2017). European bioethics: A new history guaranteeing a new future. Soc. ekol. Zagreb, 26(1-2), 61-68. https://doi.org/10.17234/ SocEkol.26.1.5.

Nader, R. (1965). Unsafe at any speed: The designed-in dangers of the American automobile. New York: Pocket Books (PB Special). 
Rawls, J. (1971). A theory of justice. Cambridge, MA: Belknap Press of Harvard University Press.

Rothman, D. (1991). Strangers at the bedside: A bistory of how law and bioethics transformed medical decision making. New York: Basic Books.

Salgo v. Leland Stanford, Jr., University Board of Trustees, 154 Cal. App. 2d 560, 317 P. 2 d 170 (1957).

Starr, P. (1982). The social transformation of American medicine. New York: Basic Books.

United Nations Educational, Scientific and Cultural Organization. (2005, October 19). Universal declaration on bioethics and buman rights.

United Nations Educational, Scientific and Cultural Organization. (2015). Global bioethics: What for? 20th anniversary of UNESCO's Bioethics Programme. Paris: UNESCO. http://unesdoc.unesco.org/images/0023/ $002311 / 231159$ e.pdf.

Open Access This chapter is licensed under the terms of the Creative Commons Attribution-NonCommercial-NoDerivatives 4.0 International License (http:// creativecommons.org/licenses/by-nc-nd/4.0/), which permits any noncommercial use, sharing, distribution and reproduction in any medium or format, as long as you give appropriate credit to the original author(s) and the source, provide a link to the Creative Commons license and indicate if you modified the licensed material. You do not have permission under this license to share adapted material derived from this chapter or parts of it.

The images or other third party material in this chapter are included in the chapter's Creative Commons license, unless indicated otherwise in a credit line to the material. If material is not included in the chapter's Creative Commons license and your intended use is not permitted by statutory regulation or exceeds the permitted use, you will need to obtain permission directly from the copyright holder.

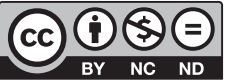

